\title{
Practical Analysis of the Integration Mode of Teaching and Training of Aerobics in Colleges and Universities
}

\author{
Weidong Ran \\ Sichuan University of Arts and Science, Dazhou, China \\ Email: 17347902@qq.com
}

How to cite this paper: Ran, W.D. (2020) Practical Analysis of the Integration Mode of Teaching and Training of Aerobics in Colleges and Universities. Open Access Library Journal, 7: e6826.

https://doi.org/10.4236/oalib.1106826

Received: September 16, 2020

Accepted: October 27, 2020

Published: October 30, 2020

Copyright $\odot 2020$ by author(s) and Open Access Library Inc.

This work is licensed under the Creative Commons Attribution International License (CC BY 4.0).

http://creativecommons.org/licenses/by/4.0/

\section{(c) (i) Open Access}

\begin{abstract}
With the progress and development of the society, the level of education and teaching in colleges and universities is also constantly improving, and they pay more and more attention to the discussion about the new teaching mode. In the teaching of aerobics in colleges and universities, how to realize the integration mode of teaching and training is considered to be a long-term and complex but practical work. By using the integration mode of teaching and training of aerobics, we can effectively improve the effect of teaching and training of aerobics in colleges and universities and realize the innovation of classroom. This paper mainly analyzes and discusses about the problems related to the construction of the integration mode of teaching and training of aerobics in colleges and universities. I hope that it can help to improve the level of teaching and training of aerobics in colleges and universities.
\end{abstract}

\section{Subject Areas}

Education

\section{Keywords}

University Education, Training of Aerobics, Teaching and Training, Integration Mode, Method Exploration

\section{Introduction}

Aerobics is becoming more and more popular because of its good exercise effect and ability to transmit a lot of positive energy, so that colleges and universities pay more attention to setting up aerobics courses. But at the present stage, there is no unified teaching material and course content system for the aerobics course 
in our physical education institute. In the past, the aerobics course set-up only paid attention to skills, but ignored the cultivation of ability. It is disadvantageous to the stability of the long-term development of Calisthenics course, which leads to the weak effect of Calisthenics class in colleges and universities. Therefore, the exploration of the integration mode of teaching and training is considered to be an effective way to improve the effect of aerobics courses in colleges and universities [1].

\section{Application Goals of the Integration Mode of Teaching and Training of Aerobics in Colleges and Universities}

Just as its name implies, the integration mode of teaching and training of aerobics in colleges and universities is a new teaching mode that combines the theoretical knowledge of teaching of aerobics with the training practice. Through the integration mode, it is intended to realize the interaction between theory and practice of the teaching of aerobics, effectively increase the enthusiasm of college students to learn aerobics, and enhance the motivation of college students to practice aerobics, so as to promote the improvement of teaching effect of aerobics in colleges and universities.

Overall speaking, the application of the integration mode to the teaching and training of aerobics in colleges and universities is mainly to improve the practical ability of college students and cultivate the integrated talents with good theory and practice. It is consistent with the overall trend of the need for applied talents by the economic and social development at the current stage [1]. Through the application of the integration mode of teaching and training of aerobics in colleges and universities, college students have more opportunities to contact the society with aerobics as the media, so as to obtain opportunities and stage. It can help college students to be integrated into society, broaden their horizons and cultivate the positive and healthy mentality.

\section{Obstacles to the Construction of the Integration Mode of Teaching and Training of Aerobics in Colleges and Universities}

The setting up of aerobics courses in colleges and universities started late in the education system of colleges and universities in China. Although its development has the trend of catching up, there are still some problems that hinder the construction and application of the integration mode of teaching and training of aerobics in colleges and universities according to the analysis on its current conditions [2]. The specific problems include the shortage of teaching and training funds, insufficient supporting resources and the imbalance of teaching time and training time. The specific analysis is as follows:

1) Shortage of teaching and training funds

For aerobics, many colleges and universities have not set up the special support funds. Even teams participating in the contests are relatively short of teach- 
ing and training funds. On the one hand, it is mainly affected by the lack of corresponding polities and regulations by relevant national departments. On the other hand, aerobics in colleges and universities started late, so that they have not been fully integrated into the teaching system of colleges and universities. For colleges and universities, the funds are very limited [2]. In the current environment, it is difficult to stably and continuously invest funds to support the analysis and application of the integration mode of teaching and training of aerobics, which will affect the effect and progress of the construction of the integration mode of teaching and training of aerobics. It will reduce the enthusiasm and confidence of teachers who vigorously promote the construction of the integration mode and they may give up.

2) Insufficient supporting resources

The problem of insufficient supporting resources for the integration of teaching and training of aerobics in colleges and universities mainly has two aspects: venues and facilities and professional teachers. First, the teaching and training of aerobics is collective. The venues which can accommodate the participants of teaching and training and necessary facilities and equipments are required. In addition, aerobics is a professional and systematic sport. Although colleges and universities cannot set the course objectives according to the requirements of professional athletes, there should be teachers of relevant majors to provide students with correct and scientific guidance, achieve the effect of teaching and training, and avoid physical harm to students due to irregular movements or improper training methods [3]. However, the problem of insufficient supporting resources of these two aspects is universal in colleges and universities in China. As an important part of the integration of teaching and training of aerobics in colleges and universities, insufficient supporting resources have a far-reaching impact.

3) Imbalance of teaching time and training time

As the analysis on the integration mode of teaching and training of aerobics in colleges and universities has started, it is necessary to arrange the teaching and training time according to the specific teaching objectives and course requirements. However, some colleges and universities pay attention to professional courses, and position aerobics courses as elective courses, but not required courses, so that it is difficult to unify the time of students. Moreover, even if the teaching and training of aerobics is specially arranged in the education and teaching system of colleges and universities, the time is short and fragmented because we cannot pay attention to the importance of aerobics courses [3]. Therefore, there is not enough time to apply and practice the integration mode of teaching and training of aerobics in colleges and universities, so that we cannot accumulate the corresponding experience, the construction of the integration mode is hindered and the process slows down.

\section{Construction Method of the Integration Mode of Teaching and Training of Aerobics in Colleges and Universities}

The construction of the integration mode of teaching and training of aerobics in 
colleges and universities is essentially an innovation of the classroom form. In the specific application, the focus is the breakthrough in teaching mode, space, teachers and other aspects [3]. The construction method of the integration mode of teaching and training of aerobics in colleges and universities is analyzed as follows:

1) Upgrade the setting of aerobics course in colleges and universities

For the construction of the integration mode of teaching and training of aerobics in colleges and universities, it should be placed in a position different from other courses in the education and teaching system of colleges and universities. It should be separated from the original required and elective courses and set up in the name of "second classroom", "social practice" and "quality training", so as to establish the integration mode of teaching and training of aerobics in the form of course setting. In addition to upgrading the setting of aerobics courses in colleges and universities in form, we should also pay attention to the upgrading the teaching objectives of aerobics courses in colleges and universities [4]. The basis for the upgrading of setting is the social practical requirements, such as launching of aerobics activities at the social level, specific requirements of competitions at all levels and the development of aerobics in advanced areas. Only in this way we can ensure the advanced integration mode of teaching and training of aerobics in colleges and universities, ensure the achievement of the education and teaching objectives in the integration mode of teaching and training of aerobics in colleges and universities, and show practicality and sociality.

2) Carry out the optional teaching of aerobics courses in colleges and universities

Aerobics itself is systematic. It has a lot of movements and routines, and the difficulty layers are obvious, so that aerobics has a high promotion value and wide audiences. Therefore, in the integration mode of teaching and training, the optional teaching of courses should be carried out for aerobics in colleges and universities. That is, after entering the aerobics teaching environment, students who participate in teaching and training can make a variety of choices according to their physical quality, interest and familiarity with and favor of teachers. When carrying out the optional teaching of aerobics courses in colleges and universities, we should break the framework of class and grade [4]. In the fixed environment and time, students should integrate into a teaching and training group, which greatly improves the evaluation effect between students and teachers and implements the open teaching and training. If there is a competition or sports meeting, students who participate in the optional teaching can be selected to meet different practical requirements.

3) Graded assessment of aerobics course in colleges and universities

After the completion of the optional teaching of aerobics courses in colleges and universities, the student level structure in the integration mode of teaching and training of aerobics can be basically formed. There are different teaching and training groups, such as primary, intermediate and advanced groups, which 
is also the basis for the implementation of graded assessment of aerobics courses in colleges and universities. The implementation of graded assessment of aerobics course in colleges and universities can ensure the fairness and justice of the assessment results, realize the healthy competition and consciousness stimulation among students at the same level, and promote the transformation of the assessment of aerobics courses in colleges and universities from a single examination to ability assessment. In this way, we can help students to consolidate the learning achievements of aerobics and gradually realize the comprehensive cultivation of theoretical knowledge and practical ability of aerobics [3]. In the process of the implementation of graded assessment, different assessment contents and standards should be developed for students at different stages. For example, the assessment standards for students in the primary class should be based on whether the meet the requirements, the attitude of participating in teaching and training and other aspects with a large proportion. Students in the intermediate class can be encouraged to independently compose aerobics on the basis of the completion of basic movements or routines [4]. Students of the advanced class can be measured according to the standards of the competition. On the one hand, it can improve the level of students in the advanced class, recognize the ability of students in the advanced class by improving the assessment standards and improve their self-confidence. On the other hand, it can find talents and train backbones for the university to participate in aerobics competitions at all levels.

4) Encourage the differentiated development of aerobics courses in colleges and universities

The setting up of aerobics course in colleges and universities is not only to enhance the physical fitness of college students, but also to stimulate their creativity and teamwork, guide them to establish a healthy personality and develop a positive attitude. Therefore, based on the characteristics of aerobics, such as openness, enthusiasm and freedom, in the process of implementation of the integration mode of teaching and training of aerobics in colleges and universities, it is necessary to master the balance between the unity of the mode and the individual development of students, and encourage students to pursue differentiated development, highlight their own personality and express their personal demands in the aerobics courses of colleges and universities. According to the students' desire for differentiated development and demands for personality development, aerobics teachers should adjust the teaching and training programs appropriately, make characteristic teaching and training plans when necessary, and help and guide students to develop and grow. Through the differentiated development, in essence the comprehensive quality, ability, creativity and imagination of students are improved, and applied and practical talents are cultivated [5].

\section{Conclusion}

In order to carry out the integration mode of teaching and training of aerobics in 
colleges and universities, we should avoid the formalization, define the direction and thinking of implementation of the integration mode of teaching and training of aerobics, give necessary support and adequate guarantee in form, system and material, and clear the obstacles in the implementation of the integration of teaching and training of aerobics in colleges and universities. Moreover, in the process of exploration of the integration mode of teaching and training of aerobics in colleges and universities, we should combine the national talent demands and strategic policies, so as to add macro elements to the setting of the integration mode plan of teaching and training of aerobics, improve the standing vision, and ensure the effectiveness of the implementation of the integration mode of teaching and training of aerobics.

\section{Conflicts of Interest}

The author declares no conflicts of interest regarding the publication of this paper.

\section{References}

[1] Li, J.K. and Tao, N. (2020) Thinking about the Reform of Aerobics in Ordinary Colleges and Universities. Sports Goods and Technology, No. 14, 138-139.

[2] Guo, T.R. (2019) Research on the Construction of the Integration Mode of Teaching and Training of Aerobics in Colleges and Universities. Boxing and Fighting, No. $18,108$.

[3] Jiang, J.L. and Zeng, Z. (2019) Research on the Integration Mode of Classroom Teaching and Extracurricular Training of Aerobics in Colleges and Universities. Contemporary Sports Science and Technology, No. 24, 95-96.

[4] Che, Z.W. (2019) Research on the Integration Mode of Teaching and Training of Aerobics in Colleges and Universities. Electronic Journal of New Education Era (Teacher's Edition), No. 12, 131.

[5] Chen, X.Y. and Li, J.Y. (2018) Analysis of the Integration Mode of Teaching and Training of Aerobics in Colleges and Universities. Sports Time and Space, No. 24, 266. 